\title{
Türk ve Rus Edebiyatında Süslü Nesir*
}

\author{
Dr. Öğr. Üyesi Kevser Tetik \\ Anadolu Üniversitesi \\ Edebiyat Fakültesi, Rus Dili ve Edebiyatı Bölümü \\ kevser_tetik@anadolu.edu.tr \\ Öz
}

\author{
Ö̆gr. Gör. Gönül Yüksel (iD \\ Anadolu Üniversitesi \\ Rektörlük, Türk Dili Bölümü \\ gyuksel@anadolu.edu.tr
}

Süslü nesir, klasik Türk edebiyatının başlıca nesir türlerinden biridir. Dönemin önde gelen edebî türü olan nazmın etkileyici gücü, nesri de etkiler. Bunun sonucunda ise nazımdaki gösterişli mecazlara, çeşitli edebî sanatlara bolca yer verilen, ağdalı bir dil ile yazılan secilerin ağırlıkta olduğu âhenkli ve ritmik bir tınısı olan süslü nesir ortaya çıkar. Klasik Türk edebiyatında süslü nesir türünün ilk örneği XV. yüzyılda Tazarru'nâme adlı eseriyle Sinan Paşa tarafından verilmiştir. Bu nesrin diğer temsilcileri arasında Fuzuli, Veysi, Nergisi gibi yazarlar bulunmaktadır. Rus edebiyatında da süslü nesrin (орнаментальная проза) temelleri ilk olarak XV. yüzyılda Epifaniy Premudrıy tarafından ağdalı bir dille kaleme alınan Stefan Permskiy'nin Yaşamı (Житие Стефана Пермского) ve Sergiy Radonejskiy'nin Yaşamı (Житие Сергия Радонежского) eserlerinde görülür. Rus edebiyatında süslü nesrin kökenleri, XV. yüzyıla dayansa da süslü nesir, neorealizm ile başlayan yeni üslup arayışlarının bir sonucu olarak 1920'li yıllarda ortaya çikmıştır. Söz konusu çalışmada karşılaştırmalı olarak genelden özele bir anlatımla Türk ve Rus edebiyatındaki süslü nesrin ortaya çıkışına, gelişim evrelerine, üslup özelliklerine, ortak yanlarına ve farklılıklarına açıklık getirilmiştir. Bu bağlamda süslü nesre ait çeşitli eserlere ait parçalardaki söz ve anlam sanatları ve uyaklar analiz edildiğinde, her iki edebiyatın süslü nesir örneklerinde de yoğun benzerlikler görülmüş, ağırlıklı olarak kullanılan sanatsal anlatımın, temelde sanatçıların estetik kaygısına dayalı olarak gerçekleştirildiği tespit edilmiştir.

Anahtar Kelimeler: Süslü nesir, Türk edebiyatı, Rus edebiyatı.

\section{Ornate Prose in Turkish and Russian Literature*}

\section{Abstract}

Ornate prose is one of the main types of prose in the classical Turkish literature. The impressive power of poetry, the leading literary genre of the period, also influenced prose. Ornate prose, characterized by flashy metaphors, various literary arts, elaborated language, predominant internal rhyme (seci), harmonious and rhythmic resonance, emerged as the result of this influence. The first example of ornate prose in the classical Turkish literature is

* Söz konusu makale, Bandırma Onyedi Eylül Üniversitesi tarafından 26 Eylül 2019 tarihinde Balıkesir'de düzenlenen Uluslararası Filoloji Konferansı'nda sunulan bildirinin genişletilmiş hâlidir.

* This article is the expanded version of the paper presented at the International Philology Conference organized by Bandırma Onyedi Eylül University on September 26, 2019 in Balıkesir. 
the 15th-century 'Tazarrunâme' by Sinan Pasha. Other representatives of this prose are Fuzuli, Veysi, Nergisi, to name just a few. In the Russian literature, the origins of ornate prose were first seen in the 15th century in such hagiographies as Life of Stefan of Perm and Life of Sergius of Radonezh by Epiphanius the Wise. Although its origins in the Russian literature date back to the 15th century, the ornate prose reappeared as a result of the search for new styles starting with neorealism in the 1920s. This study sets out to clarify the emergence of ornate prose in the Turkish and Russian literatures, its developmental stages, stylistic features, common aspects, and differences comparatively from the general to the specific. In this context, when the rhetoric and semantic arts and rhymes in the pieces belonging to various works belonging to the ornate prose were analyzed, deep similarities were observed in the ornate samples of both literature and it was determined that the artistic expression that is used was carried out mainly based on the aesthetic concerns of the artists.

Keywords: Ornate prose, Turkish literature, Russian literature. 


\section{GİRIŞ}

Edebiyatta anlatım, nazım ve nesir olarak iki tür üzerinden yapılagelmektedir. Nazmın genel olarak hayal gücüne, gönle, ruha hitap eden, duygu coşkunluğu yaratan bir gücü vardır. Nazım, duyguları konuşturan bir sanattır. Nesir ise çoğunlukla vezinsiz ve kafiyesiz düz cümleler hâlinde yazılan, bazı edebiyat dönemlerinde ise nazımla iç içe olan edebî bir tür olarak bilinmektedir.

Nesirde en önemli ve en temel koşul, içinde bulunduğu dilin kuralları dâhilinde oluşturulmuş olmasıdır. Nazım dili ise, gündelik dilden farklı olarak kendi hedefi doğrultusunda hareket eden âhenkli bir dinamiğe sahiptir. Bu dinamiği, dilin bütün olanaklarını rahatça kullanabilme özgürlüğünden kaynaklanmaktadır. Çağrışımlar, çok anlamlılık, yan anlamlar, eğretileme, mecaz vb. türden metotların yarattığı olanaklar, nazmın anlam dünyasının sinırlarını genişletir. Bazen anlam, bu sanatlarla, imgelerle kapatılarak okuyucunun hissiyatına, kişisel anlayışına ve sezgisine bırakılabilir. Ancak nesir dili, toplumu ya da bireyi eğitici, bilgilendirici, yerine göre yönlendirici bir görev üstlenir.

Nazmın ve nesrin ne zaman ortaya çıtığı, hangisinin önce doğduğu bilim insanları arasında daima tartışılan bir husus olmuştur. Nazmın önce ortaya çıktığı nesrin ise şartların gelişmesiyle daha sonra kendini gösterdiği yaygın bir görüş olarak savunulmaktadır. $\mathrm{Bu}$ tartışmaya değinen Süleyman Çaldak, dilbilgisi uzmanlarıyla diğer sosyal bilimcilerin bu konudaki görüşlerini ele alarak dilbilgisi uzmanlarının, nesrin nazımdan önce geldiğini; diğer sosyal bilimcilerin ise destan, trajedi, halk şiiri gibi manzum eserlerin, dinî ayinlerden doğduğunu savunduklarına işaret eder. Bu düşüncelere dayanarak Çaldak, nazmın dinî bir ritüel olarak ortaya çıktığını; ancak uzun bir süre sonra din dışı ve bağımsız bir sanat hâlinde varlık gösterdiğini; nesrin ise düşüncenin gelişimiyle sonradan vücut bulduğunu vurgular (2006, s. 75).

Türk edebiyatında nesrin ortaya çıkışı tarihsel olarak incelendiğinde Türk nesrinin, farklı dönemlerde farklı özelliklere sahip olduğu görülür. Her ne kadar Türk nesir geleneğinin geçmişi, İslamiyet öncesinde Orhun Abideleri'ne ve Uygur metinlerine dayansa da genelde olduğu gibi Türk edebiyatında da nesir türünün gelişiminin nazımdan daha sonra gerçekleştiği düşüncesi oldukça yaygındır. Türk nesrinin ilk ve en önemli örnekleri olan bu eserler genellikle açık ve sade bir dile sahip didaktik, yer yer lirik, destanî ya da dinî içerikli eserler olarak karşımıza çıkar. Eski Türk edebiyatı araştırmacısı Mine Mengi bu konuda şöyle bir açılama yapmaktadır:

Başlangıçta Türklerin yer değiştirmeleri sonucu siyasî birlik ve düzene kavuşmalarının
zaman alması, yerleşik düzen ve huzur isteyen edebiyatın özellikle de düşünce temeline
dayanan nesrin hemen gelişip güçlenmesini engellemiştir. Bu tarihî gelişmeyle birlikte;
duygusallı̆̆ı, akıcılığı, kısalığı dolayısıyla akılda daha kolay kalması vb. özellikleri
geçmişin hemen her döneminde şiiri öne çıkarmıştır. Bu bağlamda, derecesi ne olursa
olsun, ağırlıklı olarak lirik içerikli olan Divan şiirinde de şïr nesre göre daha etkili bir
iletişim aracı olarak öne geçmiş ve estetik beklentinin şiir aracılığıyla karşılanması yoluna
gidilmiştir. Dolayısıla edebiyatta hüner ve marifet, şiirle var sayılmış; şiir, edebi gücü
gösterme aracı olarak kabul görmüştür (2007, s. 43-44).

Edebiyat sahasında hangisinin önce doğduğu tartışılagelse de nazım ve nesrin birbirinden ayrılmaz bir bütün olduğu mutlak bir gerçektir. Çünkü nazım ve nesir, biçimsel özellikleri ve konuları bakımından birbirlerinden ayrılsalar da dönem dönem kendi kurallarının dışına çıkarak birbirlerinin sınırlarını zorlamış, birbirlerinin özelliklerinden 
beslenmiştir. Bu iki türün, yüzylllar boyunca kimi zaman birbirinin içinde yer aldığı ve kimi zamansa birbirine benzemeye çalıştığı güzel örnekleriyle karşılaşmak mümkündür. Hemen hemen her kültürün edebiyatında, özellikle sanatlı nesrin, nazmın sahasına daldığı, onun özelliklerini kullanarak ritmine, âhengine ulaşmaya çalıştığı dönemler olmuştur.

Rus edebiyatının gelişimi de Türk edebiyatında olduğu gibi nesir ve nazmın aktif etkileşimi ve iç içe geçmesiyle gerçekleşmiştir. Aleksandr Puşkin, bu düşünceyi şiir romanı Yevgeniy Onegin'de şu sözleriyle destekler: "Onlar birleştiler // Dalga ve taş, // Nazım ve nesir, buz ve alev // Birbirinden çok da farklı değiller" (1937, s. 42). Sovyet edebiyat bilimci, şiir kuramcısı ve metin bilimci Boris Viktoroviç Tomaşevskiy'e göre "Nazmı ve nesri net sınırları olan iki alan olarak değil; tarihsel olarak gerçek olgularla çevrilen iki kutup, iki çekim merkezi olarak ele almak daha doğru ve tabii olacaktır" (1959, s. 7-8).

Rus edebiyatının panoramasını genel hatlarıyla ele aldığımızda her edebiyat döneminde farklı edebî eğilimlere ve türlere rastlandığı görülür:

Rus edebiyatında XI. yüzyıla kadar halk edebiyatı hâkimdir. Bu dönemde bılina (былина), tarihî şarkı (историческая песня), efsane (дегенда), epik halk hikâyesi (сказ) türlerinde anonim eserler görülür. Söz konusu eserlerin birçoğu nazım formunda söylenmiştir. Nesir formunda söylenen eserlerde ise ritim ve kafiye sağlanarak, esere şiirsellik verilmiştir. Böylece halk edebiyatı eserlerinin kolaylıkla akılda kalması ve ağızdan ağıza aktarılması sağlanmıştır ki, bu özelliğin Türk edebiyatında da benzer şekilde geliştiği görülür.

988 yılında Hristiyanlığın kabulü ile birlikte Rus edebiyatının oluşum süreci başlar. Eski Rus Edebiyatı döneminde (XI-XVII. yüzyıllar) nesir, baskın türdür. Vakayinâme (летопись), azizlerin yaşam öyküsü (житие), seyahatnâme (хождение, хожение), vaaz (проповедь) türlerinde yazılan eserlerde dinî ve tarihî kişilikler ele alınmıştır. XV. yüzyılda azizlerin yaşam öyküleri ağdalı bir dille yazılmış ve süslü nesrin temelleri atılmıştır. XVII. yüzyılda ise sıradan insanın yaşamı ve iç dünyası edebiyatta kendisine yer bulabilmiş, drama ve nazım türlerinde eserler verilmeye başlanmıştır.

XVIII. yüzyıl Rus Edebiyatı'nın ilk yarısında baskın edebî tür olarak nazım karşımıza çıkar. Bu durum, dönemin edebiyat akımının klasisizm olması ile açıklanabilir. Eserlerinde bu akıma başvuran yazarlar yoğunluklu olarak od (ода), sone (сонет), destan (эпическая поэма), eleji (элегия), fabl (басня) gibi nazım türlerine yönelirler. XVIII. yüzyılın ikinci yarısından itibaren ise klasisizmin tiyatro türleri olan trajedi, komedi ve drama yönelim başlar. XVIII. yüzyılın sonlarında santimentalizmin ortaya çıkışıyla nesir türü, yazılan hikâyeler aracılığıyla ilk kez nazma oranla daha çok kullanılmaya başlanır.

XIX. yüzyılın başlarında Rus edebiyatında etkili olan akım romantizmdir. Bunun doğal bir sonucu olarak balad (баллада) ve poema (поэма) gibi türlere yönelim yaşandığ için nazım, nesre oranla daha fazla öne çıkar. XIX. yüzyılın ilk çeyreğinden itibaren Rus edebiyatında realizm etkili olmaya başlar ve yazarlar romanla hikâye türlerine yönelirler. Rus Edebiyatının Altın Çă̆ı olarak adlandırılan bu dönem gücünü nesirden alır.

XIX. yüzyılın sonu XX. yüzyılın başını kapsayan dönem ise Gümüş Çă̆ olarak adlandırılır. Sembolizm, akmeizm, fütürizm, yeni köy şiiri, imgecilik gibi akımların görüldüğü söz konusu dönemde etkin olan tür nazımdır. 
1920'li yıllarda ise Sovyet Edebiyatı'nda neorealizm ile birlikte yeni üslup arayışları görülür. Güçlü nesir dönemi olan Altın Çağ'dan sonra gelen, nazmın baskın olduğu Gümüş Çă̆ döneminden itibaren nesir ve nazım arasındaki sınırlar kaldırılır. Nazım ve nesrin iç içe geçmesiyle süslü nesir ortaya çıkar. Süslü nesir türünün ilk örnekleri, ağdalı nesir, "sözcüklerin örgüsü" şeklinde XV. yüzyılda görülse de süslü nesrin başlangıcı ve en yoğun görüldüğü dönem olarak 1920'li yılllar kabul edilir.

\section{TÜRK EDEBIYYATINDA SÜSLÜ NESİR}

Süslü nesir türü, Türk edebiyatında Rus edebiyatında olduğu gibi ilk kez XV. yüzyılda görülür. Klasik Türk Edebiyatı döneminde dil ve üslup bakımından gösterdiği özelliklerle varlı̆̆ını hissettiren süslü nesir (inşâ), Arapça ve Farsça sözcüklerin ve tamlamaların ağırlıkta olduğu, halk dilinden tamamen uzaklaşıp sanatçının sanatını ortaya koyma endişesinin ön planda bulunduğu, bol secili, süslü, sanatlı, zaman zaman yapmacıklı ve ağdalı bir dil sergileyen nesir türüdür.

Sanatlı nesrin (süslü nesrin) XV. yüzyıldaki en büyük temsilcisi Sinan Paşa'dır. En önemli eseri Tazarru'nâme, sanatlı Türk nesrinin ilk büyük eseridir. Sinan Paşa (ö.1486) doğal bir söyleyiş içinde, Arapça ve Farsça sözcüklerle zengin bir söz varlı̆̆ı oluşturarak edebiyat diline katkı sağlamış, Türkçenin ifade imkânlarının tümünden yararlanarak kısa ve simetrik, düz ve devrik, secili ve âhenkli sağlam cümlelerle mükemmel bir nesir dili meydana getirmiştir (Çaldak, 2006, s. 76).

Sinan Paşa dışında, Tezkirecilik sahasında Âşık Çelebi, Sâlim, Safâyî gibi sanatçılar, bazı resmî ve özel yazışmaları içine alan mecmua (münşeât) yazarları süslü nesir üslubunu kullanmışlardır. Fuzûlî'nin Şikâyetnâme'si, Nergisî'nin Hamse'si, Veysî'nin Münş̧eât'ı ve Dürretü't Tâc adlı siyer kitabı, bu nesrin en uç örnekleri olarak gösterilebilir.

Türk edebiyatında süslü nesrin (inşâ) genel özellikleri ele alındığında şu özellikler görülür:

Süslü nesre ait metinlerde Arapça ve Farsça sözcükler, tamlamalar ve anlam grupları kullanılır. Örneğin, süslü nesrin örneklerinden Latifî Tezkiresi'nde bol miktarda Farsça ve Arapça tamlamaların ve sözcüklerin kullanıldığı; cümlelerin $\ddot{u}$ bağlacıyla ve -Ip zarf-fiiliyle birbirine bağlanarak uzadığı dikkati çekmektedir.

\footnotetext{
Zebân-1 Türkîde şi'r ü inşâya müte'allik ne kadar dîvân ü risâle vü dâstân ü makâle var ise tetebbu' u tefahhus kuldim ve müddet-i mütemâdî sâl-hūrde vü rūzgâr-dîde, sühânşinâs ü efsâh-nâs azîzlerden istifsâr ü isti'lâm édüp fuzalâa sohbetlerinde ve bülegâa cem'iyyetlerinde mahall ü münâsebetle okunan şi'r-i rengîni ve sahâyif-i havâtıryârânda ve defâtir-i zamâyir-i ehl-i irfânda bulunan nazm-ı güzîni, şu'arâ-yı Rūmun mü'ellefât ü musannefâtı ile cem' édüp... (Gülsevin, Turan, Kartallığlu, Develi \& Duman, 2012, s. 30).

(Türk dilinde (Türkçe) nazım ve inşâ ile ilgili ne kadar divan, risale, destan makale varsa araştırıp inceledim ve sürekli olarak eski yıllardan görmüş geçirmiş sözün kıymetini bilen düzgün anlatıml güzel sözlü değerli insanlardan (selam edip) ve bilgi isteyip ve bilginler sohbetlerinde belâgat sahiplerinin toplantılarında bulunup ilgilenerek okunan süslü, hoş nazımı ve dostların hatıralarının sayfalarında ilim sahibi kişilerin defterlerinde bulunan eşsiz nazımlarını, Anadolu şairlerinin yazılmış eserlerini ve tasnif edilmiş kitaplarını toplayıp bir araya getirerek....)
} 
XVII. yüzyılda yazılmış olan ve ilk Türkçe telif siyer kitabı olarak kabul edilen, Veysî'nin Dürretü't-Tâc'ından alınan aşağıdaki örnekte Farsça ve Arapça tamlamaların bolca kullanıldığı böylece anlatımın ağır ve ağdalı bir hâl aldığı, anlamın neredeyse geri planda kaldığ1 görülür.

\begin{abstract}
...Ol eyyâmda âyîn-i sanâdîd-i Kureyş bu idi ki evlâdın kerâyim-i murzi'ât-ı kabâyile virüp kendileri ezvâc-l tâhirât ve zenân-l tayyibât ile fârig-ül-bâl gunûde-yi firậs-ı kurbet olurlar idi ve te'affün-i hevâ-yı şi'âb ve harâret-i rîk-i bathâdan gül-i nevbahar-ı 'ömr-i nâzenîn olan etfâl-i nâz-perver ve hurd-sâlî hevâ-zede-yi sümûm-i helâk olmakdan sakinurlardı. Binâenaleyh fasl-ı bahâr u hazânda havâle-nişîn-i Ka'betullâh olan zenân-ı kabâyil Mekkeye etfâl-i Kureyşiyân alup her birin zill-ı refref-i hargâhda bedeviyâne terbiyet idüp hengâm-ı rizâ' hitâm-ı fitâma yitdükde yine getürüp teslîm-i âbâ vü ümmühât iderleridi (İz, 1996, s. 7).
\end{abstract}

Süslü nesre ait diğer özellik ise metinlerde anlam ve sözle ilgili benzetme, istiare, mecaz gibi sanatlara ve tasvirlere sıkça yer verilmesidir.

Sinan Paşa'nın Tazarru'nâme'sinde benzetme ve mecaz gibi sanatlara ve tasvirlere sıklıkla başvurulmuştur. Örneğin: Terennüm-i bülbülân-ı bustân menâbir-i escârda senâ-yı kudretüñn-içün; tebessüm-i gülbünân-l gülüstân fasl-ı bahârda ta'accüb-i hikmetüñn-içün (Çev: Ağaçların kürsülerinde (dallarında) gül kokulu bahçenin bülbüllerinin şarkıları senin kudretini övmek içindir) (Tulum, 2001, s. 21). Cümlede bahar mevsiminin güzelliğinin Allah'ın hikmeti ve kudreti sayesinde olduğundan bahsedilir ve Allah'a övgüler yağdırılır.

Metinde bahar mevsimi tasvir edilirken secili anlatımın yanı sıra teşbih (benzetme), teşhis (kişileştirme) ve intak (konuşturma) sanatlarına da yer verilmiştir:"Tebessüm- $i$ gülbünân-ı gülüstân" tamlamasında "gül ağacinın tebessüm etmesi" teşhis sanatı olarak karşımıza çıkar, "menâbir-i escârda" tamlamasında ise ağaçların hutbe okunan minberlere, kürsüye benzetildiği görülür. Sanatçı, hüsn-i talîl sanatına başvurarak görsel ve somut bir tablo çizmek suretiyle bu tablonun oluşumunu soyut olan manevi ve ilahî sebebe dayandırarak Tanrı'ya övgüler sunmuştur.

Süslü nesre ait bir diğer özellik ise simetrik olarak kullanılan benzer seslerle oluşturulan seciler, redifler, aliterasyonlar ve tekrarlar sayesinde bir ritim ve âhenk elde edilmesidir. Sinan Paşa'nın Tazarru'nâme'si secili, birbirine paralel kısa cümlelerle bezenmiş bir edebî metindir, aynı zamanda âdeta nesrin mensur bir nazıma dönüşmüş hâlidir: İlâhî! Sen ol pâdişâhsin ki, lutfun hazînesi bî-pâyân; keremûn deryâsı bî-kerân. Cûdun sehâb-i kâyim; feyzun bârân-1 dâyim. Rahmetün in'âm-ı șâm il; kudretin âsâr-l kâmil. Cûdun denizinden dü âlem bir katre; mihrün havâsında iki cihân bir zerre (Tulum, 2001, s. 81). Bu satırlardaki bî-pâyân,bî-kerân; kâyim, dâyim; şâm il, kâmil; katre, zerre sözcükleri arasındaki simetrik seciler oldukça dikkat çekicidir.

Söz konusu eserin "Kadim'dur ki, ukul-i mutekaddimin ve mute'ahhirin dayire-i kıdemine kadem basamaz; Hakim'dur ki, hukema-yl evvelin $u$ ahirin hikmeti ma'rifetinden dem uramaz"(Tulum, 2001, s. 32) cümlelerinde ise "Kadim'dur ki" "Hakim'dur ki," sözcükleri ile cümle başında; "kadem basamaz", "dem uramaz" sözcükleri ile de cümle sonunda vezin ve ses birliği sağlanarak seci oluşturulmuştur. Aynı zamanda bu örnekte " $m$ " sesine dayalı kuvvetli aliterasyon görülür:

Tazarru'nâme eserinde aliterasyonlara başvurulduğu gibi asonanslara da

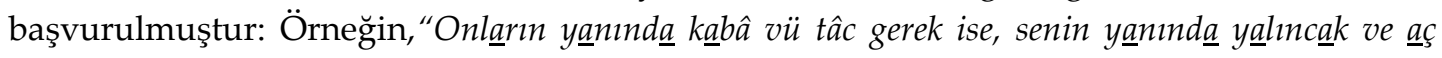


gerek" (Tulum, 2001, s. 191) cümlesinde " $a$ ", ... "hevâcir-i beydâ-y1 mahşęrde sẹr-gẹrdân gęzerlęr" ... cümlesinde ise " $e$ " sesine dayalı asonans görülür (Tulum, 2001, s. 195).

Sanatlı nesrin en önemli örneklerinden biri olan Fuzûlî'nin ünlü Şikâyetnâme'sinde de simetrik olarak kullanılan benzer seslerle oluşturulan seciler, redifler, aliterasyonlar ve tekrarlar sayesinde bir ritim ve âhenk elde edilmiştir.

\begin{abstract}
Huzurlarnna gitdüm, bir cem' gördüm, hikâyetleri perîşânne safâdan anda eser ü ne sidkdan anda nişân var. Selam verdüm, rüssvet degüldür deyü almadllar, hüküm gösterdüm, faidesüzdür deyü mültefit olmadilar. Egerçi zâhirde suret-i itaat gösterdiler, ammâ zebân-ı hâl ile cemî suâlüme cevap verdiler. Gördüm ki su'alime cevabdan gayr nesne vermezler ve bu berat ile hâcetüm reva görmezler, nâââr terk-i mücâdele kildum ve me'yûs ü mahrum gûşse-i uzletime çekildüm (Banarlı, 1998, s. 549).
\end{abstract}

Kanûnî'nin kendisine bağlamış olduğu maaşı almak üzere gittiğinde, memurların onunla ilgilenmeyip maaşını ödememeleri üzerine Fuzûlî, iğneleyici ve nükteli bir dille bu mektubu yazarak durumu ilgili devlet idaresine şikâyet etmiştir.

Süslü nesir türünde anaforlar (ön yinelemeler) ve art yinelemeler de önemli rol oynar. Sinan Paşa'nın Tazarru'nâme adlı eserinde anaforlardan oldukça yararlanılmıştır: "Ey pâdişâhı âlem, ey mûcid-i cinn ü âdem! Ey sâni-i dânâ ve ey fâil-i tüvânâ! Ey muzhir-i bedâyi-i hikem ve ey mübdi-i levh ü kalem! Ey Hâlik-ı nâr u nûr, ey râzık-ı mâr umûr!" (Tulum, 2001, s. 89). Eserde aynı şekilde art yinelemelerden de yararlanılmıştır: "Illm ü hikmet gevherlerini bildiren sensin ve iķbâl ü saâdet yolarına yeldiren sensin"(Tulum, 2001, s. 93) ..."Her kime ne evde nasîb ettin ise, takdîr senindir ve her kimi ne bölükten kıldın ise, tedbîr senindir" (Tulum, 2001, s. 161).

\title{
2. RUS EDEBIYYATINDA SÜSLÜ NESİR
}

Eski Türk Edebiyatı döneminde büyük yer tutan süslü nesir, Rus edebiyatında da kendisine yer bulmuştur. Süslü nesir, Rus edebiyatında ornamental'naya proza (орнаментальная проза), olarak karşımıza çıkar. Rus dil bilimci Dmitriy Uşakov, "ornamental'naya proza" sözünün "çok süslü, tumturakl, kasıtlı olarak oldukça karmaşıklaştırılmış" gibi anlamlara geldiğini ifade eder (2005, s. 2143).

Ağırlıklı olarak 1920'li yıllarda yazılan eserlerin büyük bir kısmında görülen süslü nesir, nesrin nazmin ilkeleri üzerine inşâ edildiği edebî bir eğilimdir. Süslü nesirde konu ikinci planda kalır; imge tekrarları, leitmotifler (леитмотивы), deyim aktarmaları [eğretileme, istiare, metafor (метафор)], çağrışımlar önem kazanır. Sözcügüün kendisi ön planda olup birçok metaforik anlam kazanır. Süslü nesirde konu değil; ses ve ritim (âhenk) ön plandadır. Süslü nesir yazarları âhengi yakalamak ve metinde çok anlamlılığı sağlamak için eserlerinde, imgelerden (образы), sembollerden (символы), ön yinelemelerden (анафоры), art yinelemelerden (эпифоры), değişmecelerden (тропы), deyim aktarmalarından, benzetmelerden, karşılaştırmalardan (сравнения), ad aktarmalarından [mecazı mürsel, metonimi (метонимия)] yararlanır.

1917-1931 yıllarında Rus edebiyatındaki yaratıcı yöntemlerin çeşitliliği, modernizmden neorealizme ve neoromantizme geçiş göze çarpar. Dönem, sosyalist realizm (Maksim Gorkiy, Aleksandr Fadeyev, Mihail Şolohov), neorealizm (Yevgeniy Zamyatin, Aleksey Tolstoy), naturalizm (Boris Pilnyak, Panteleymon Romanov), felsefi nesrin grotesk realizmi (Mihail Bulgakov, Andrey Platonov), neoromantizm (Vsevolod İvanov, Aleksandr Grin) ve nazımda romantik ile gerçekçi eğilimin sentezi (Sergey Yesenin), ekspresyonizm ve 
sembolizm (Konstantin Bal'mont, Andrey Belıy) gibi birçok akıma aynı anda ev sahipliği yapmıştır. Yaratıcı şahsiyetlerin ve edebî türlerin çeşitliliği yeni arayışlarla, bunun sonucunda da süslü nesrin ortaya çıkmasıyla sonuçlanır.

XX. yüzyılın başında Rus edebiyatında, hem nazımda hem de nesirde, pratikte kullanılan dile karşı, özel bir nazım dili oluşturma fikri hâkimdir (Kojevnikova, 1976, s. 55). Şubat ve Ekim Devrimlerinden sonra 1920'li yıllarda Rus edebiyatında yeni üslup arayışları ortaya çıkar. Bu üslup arayışları ekseninde 20'li yılların edebiyatının neoklasik nesrinde üç önemli üslup eğiliminden bahsetmek mümkündür. Bunlar: realizm akımına özgü olan geleneksel edebiyat üslubu "nötr üslup" (нейтральный стиль), nötr üslubun evrimleşmesiyle ortaya çıkan "itibarlı üslup" (авторитетный стиль) ve "otoriter üslup" (авторитарный стиль) ${ }^{1}$ tur. Edebiyat araştırmacıları bu üslup eğilimlerini yeni terimlerle, otoriter uslubu "skaz" (epik halk hikâyesi), itibarlı üslubu ise "süslü nesir" olarak, adlandırmaktadırlar (Golubkov, 2016, s. 189). Skaz, tarihsel konuların işlendiği, kahramanların köylü, işçi, küçük burjuvazi vb. sınfflarından oluştuğu ve onların ait olduğu sosyal tabakaya göre konuşturulduğu; bu yüzden sıklıkla halk dilinin, lehçenin aynı zamanda meslekî söz kalıplarının görüldüğü bir anlatı türüdür². Süslü nesir ise skazdan farklı olarak yüksek üslubun görüldüğü bir ifade türüdür.

Eski Rus edebiyatı üzerine çok sayıda çalışması olan Sovyet dilbilimci, akademisyen Dmitriy Sergeyeviç Lihaçov; "ağdalı dil" ("плетение словес") olarak tanımladığı süslü nesrin ilk kez eski Rus edebiyatında XV. yüzyılda Stefan Permskiy'nin Yaşamı (Житие Стефана Пермского) ve Sergiy Radonejskiy'nin Yaşamı (Житие Сергия Радонежского) eserlerinde görüldüğünü $(1979$, s. 286) belirtse de söz konusu nesrin ortaya çıkışı genellikle Gümüş Çağ ve modernizm ile bağdaştırılır. Rus modernizmi döneminde nazım ön plandadır. 20'li yılların başında kendisini nesirde de denemek isteyen birçok şair, geçmiş tecrübelerini reddetmeden sıra dışı bir üslup oluşturur. Nazmın nesre nüfuz etmesi; söz konusu edebiyat döneminin koşullarına uygun, uyumlu, özgün bir olaydır ve nesirde klasik olmayan bir anlatı türü olan süslü nesrin ortaya çıkmasıyla sonuçlanır (Lugovaya, 2016, s. 56). Söz konusu dönemde edebiyat ve sanat ilişkisi göze çarpar. Özellikle de edebiyat ve müzik sentezi ön plandadır. Sembolistler tarafından ilan edilen "her şeyden önce müzik" ilkesinin doğal bir sonucu olarak Sembolist nazımda yer alan birçok söz sanatı süslü nesirde de yoğun bir şekilde kullanılmaya başlanır. Böylece süslü nesirde, karmaşık ve sıra dışı sözdizimsel bir yapı, aynı zamanda fonetik sanatın tüm âhengi ve metnin ritmik yapısı görülür. Süslü nesirde daha çok leitmotiflere dayanan süslü bir nazım dili karşımıza çıkar. Nazım dilinin kullanımı, edebiyat türleri arasındaki alışılmış sınırların silinmesine ve çok anlamlı sözcüklerin kullanımındaki artışa sebep olur. Sonuç olarak, özellikle sembolist nazımda yer alan birçok sanatın yanı sıra metafor, mecaz-ı mürsel ve oksimoron ${ }^{3}$ (zıtlaşma,

1Nötr (нейтральный стиль) ve otoriter üslup (авторитарный стиль) kavramları, ünlü Rus edebiyat kuramcisı Mihail Bahtin tarafından işlenmiştir (Bahtin, 1975). 1920-1930'lu yılların edebiyatında nötr üsluptan otoriter üsluba geçiş konusunu ise edebiyat eleştirmeni ve bilimcisi Galina Belaya "Nötr Üslubun Üstesinden Gelme Süreci Olarak Yeni Üslupların Doğuşu” adlı çalışmasında ele almıştır (Belaya, 1978, s. 460). Belaya, yine aynı kitabın bir başka bölümünde "Üslup ve Zaman "İtibarl Üslup" ve Onun Sorunsalı" konusuna da yer vermiştir (Belaya, 1978, s. 431).

${ }^{2}$ Ayrıntılı bilgi için bkz.: Tetik, K. (2020). Bir skaz örneği: İsaak Babel'inTuz adlı öyküsü. O. Köse (Ed.), Siyasi, sosyal ve kültürel yönleriyle Türkiye ve Rusya içinde (C. 4, s. 205-219). Ankara: Berikan Yay.

3Oksimoron, birbiriyle çelişen ya da tamamen zıt iki kavramın bir arada kullanılmasıdır. Birçok nazım ve nesir türünde, karşıtlık üzerine kurulu oksimoron sanatıyla karşılaşmak mümkündür. Örneğin, İvan Turgenyev'in Canlı Cenazeler (Живые мощии) hikâyesinde, Lev Tolstoy'un Canlı Ceset (Живой труn) ve Vladimir Vişnevskiy'nin İyimser Trajedi (Оптимистическая трагедия) piyeslerinde olduğu gibi, bazı edebî eserlerin adlarında dahi oksimoron söz sanatının kullanıldığı görülür (Kvyatkovskiy, 2013, s. 258). 
küçük karşıtlam) gibi mecaza dayalı söz sanatlarının nesirde de yoğun bir şekilde kullanılmaya başlandığı görülür.

Dönem yazarlarının özel bir dil bulma arayışları, farklı estetik ve kısmen de felsefik ön koşullardan hareket ederek sembolizm, fütürizm, imgecilik gibi çeşitli akımlarda gerçekleşir. Sembolistlerin nazımlarında, fütüristlerin "kendi kendini oluşturan sözcük"tünde ("самовитое слово"), imgecilerin "imgesel" sözсӥğ̈̈nde özgün timsalini bulur. Bu sanatsal pratiği, söz konusu dönem için yeni olan sanatsal dilin "zorlaştırılmış", "hızı kesilmiş", "çarpıtılmış" teorik anlayışı takip eder (Kojevnikova, 1976, s. 55). Tüm bu yönleriyle süslü nesir, Rus modernizmi ve avangardının doğal bir ürünüdür.

Süslü nesrin kurucusu Andrey Belıy'dır (Şulova, 2016, s. 268). Andrey Belıy'ın Senfoniler [Dramatik Senfoni (Драматическая симфония, 1902); Киzеу Senfonisi (Северная симфония, 1904); Dönӥş (Возврат, 1905), Tipiler Kadehi (Кубок метелей, 1908)], Petersburg (Петербург, 1913) ve Kotik Letayev (Котик Петаев, 1917)] adlı eserleri süslü nesrin XX. yüzyıldaki ilk örneklerindendir. Aleksey Remizov, Rus Halkına Öğ̈̈tler (Заповедное слово русскому народу 1918) adlı eseriyle Andrey Belıy gibi süslü nesrin kurucularından biri olarak kabul edilmektedir. Süslü nesir yoğunluklu olarak 1920'lerin ilk yarısında görülür. Boris Pilnyak [Çıplak Yıl (Голый zоd, 1922)], Vsevolod İvanov [Renkli Rüzgârlar (Цветные ветра, 1922)], Aleksandr Malışkin [Dair'in Düşüşü (Падение Дaupa, 1923)], Yevgeniy Zamyatin [Biz (Mbl, 1924)], Aleksandr Serafimoviç [Demir Tufanı (Железныıй поток, 1924)] gibi yazarların eserlerinde görülen süslü nesir, 20'li yılların ikinci yarısında Mihail Bulgakov [Веyаz Muhafiz (Белая гвардия, 1925)], Maksim Gorkiy [Artamonovlarm İşis (Дело Артамоновых, 1925)], İsaak Babel [Kızıl Süvariler (Конармия, 1926)], Fyodor Gladkov [Çimento (Цемент, 1925)], Konstantin Fedin [Kentler ve Yallar (Города u zodbl, 1927)], Yuriy Oleşa [Kıskançlık (Зависть, 1927)], Mihail Prişvin [Cadının Zinciri (Кощ̧еeва цุеnь, 1927), Aleksandr Malışkin [Sivastopol (Севастополь, 1927)], Osip Mandel'ştam [Mısır Pulu (Египетская марка, 1928)], Yuriy Tinyanov [Vezir Muhtar'ın Ölümӥ (Смерть ВазирMyxmapa, 1928)] gibi yazarların eserlerinde de görülür. Süslü nesir 30'lu yıllarda da etkisini sürdürür. Vladimir Nabokov [Umutsuzluk (Отчаяние, 1934)], Vsevolod İvanov [Zırhlı Tren (Бронепоезд 14-69, 1933); [Partizan Öyküleri (Партизанские повести, 1937)], Boris Poplavskiy [Gökyüzünden Eve (Домой с небес, 1936-1938)]. 1920-1950'lerin başlarındaki sanatsal dönem; dile duyulan özel bir ilgi, dilin sözdizimsel, anlamsal, duygusal ve ritmik yoğunluğunu içinde barındıran, konuya daha fazla yaklaşmayı ve devrim döneminin bütün konuşma zenginliğini sanata taşımayı amaç edinen süslü nesrin etkisi altında varlığını sürdürür (Dragomiretskaya, 1965, s. 132). Bu edebî eğilim, XX. yüzyılın ikinci yarısında da Rus edebiyatında kendisine yer bulur. Örneğin, Varlam Şalamov'un Kolıma Öyküleri (Koлbıмские рассказы, 1966-1967), Vladimir Gusev'in Günеyin Ateşli Rüzgârı (Огненный ветер юга, 1988) ve Boris Pilnyak'ın Tüm Yaşam (Целая жизнь, 1988) adlı eserleri, XX. yüzyılın ikinci yarısında da süslü nesrin geleneklerinin önemini koruduğunun bir göstergesidir.

4"Kahrolsun araç olan sözcük, yaşasın Kendi Kendini Oluşturan, kendi başına değerli sözcük!" sloganıla bir araya gelen (İvanov, Paperniy \& Parnis, 2000, s. 135), aralarında Velimir Hlebnikov, Vladimir Mayakovskiy ve Aleksey Kruçyonıh gibi temsilcileri bulunan Rus fütüristleri, sözcügü araç olmaktan çıkarmış ve kendi başına değerli, kendi kendine anlamlı ifade unsurları olarak görmüşlerdir. Sözcügün özgürleşmesi gerektiğini savunarak eserlerinde, imlâ ve gramer kurallarının kaldırılmasından yana olmuşlardır.

5Eser, Türkçeye farklı çevirmenler tarafından Artamonov Ailesi ya da Artamonovlar olarak çevrilmiştir. Ancak söz konusu çeviriler, eserin orijinal adının (Дело Артамоновых) Türkçedeki tam karşılığı değildir.

SEFAD, 2020; (44): 85-102 
Araştırmacılar tarafından süslü nesir üslubunun farklı oluşumlarının olduğu tespit edilmiştir. Örneğin D. S. Lihaçov (1906-1999), süslü nesre XI. ve XVII. yüzyılları kapsayan Eski Rus Edebiyatı'nda da rastlanıldığından bahseder ve süslü nesri "ağdalı dil" ("nлетение словес") olarak tanımlar (1979, s. 286). Alman dil ve edebiyat bilimci, filolojide narratoloji (anlatıbilim) kuramının temsilcilerinden Wolf Schmid ise XIX. yüzyılda da süslü nesrin Aleksandr Puşkin, Anton Çehov ve Fyodor Dostoyevski gibi temsilcileri olduğunu belirtir (Schmid, 1998). Ancak süslü nesrin en parlak oluşumu Gümüş Çağ Rus nesrinde görülür. Edebî, sanatsal eğilimlerden biri olan süslü nesir, Yevgeniy Zamyatin'in, Boris Pilnyak'ın, Sergey Kılıçkov'un, Mihail Bulgakov'un ve Sovyetlerin ilk yıllarında yaşamış diğer yazarların yazın sanatında gelişmiştir (Ahmedov\& Alihanova, 2013, s. 94).

Süslü nesir üzerine çeşitli eserler yazılmıştır. Bunlar arasında Rus Biçimci yazarlardan (русские формалисты) ve süslü nesrin kuramcısı ve uygulayıcısı olan Yuriy Tinyanov'un Nazım Metninin Problemleri (Проблемы стихотворного языка, 1924); bir diğer biçimci yazar Viktor Şklovskiy'nin Nesrin Teorisi Üzerine (O mеории прозы, 1925); Natalya Alekseyevna Kojevnikova'nın Klasik Olmayan (süslü) Nesir Üzerine Gözlemlerden (Из наблюдений над неклассической (орнаментальной) прозой, 1976); Lev Alekseyeviç Novikov'un Andrey Belıy'ın Süslü Nesrinin Üslupbilimi (Стилистика орнаментальной прозы Андрея Белого, 1990); Wolf Schmid'in Narratoloji (Нарратология, 2003); Yekaterina Borisovna Skorospelova'nın 20-30'lu Yillar Sovyet Nesri: Romanin Kaderi (Русская советская проза 20-30-х годов: судьбы романа, 1985) ve XX. Yüzyıl Rus Nesri: A. Belıy'den B. Pasternak'a (Русская проза XX века: от А. Белого до Б. Пастернака) adlı eserleri ve Sergey İvanoviç Kormilov'un Gümüş Çă̆'ın Vezinleştirilmiş Rus Nesri (Русская метризованная проза Серебряного века, 2009) gibi çоk sayıda çalışma bulunur.

Araştırmacılar, yazarların süslü nesre yönelmesi konusuna çeşitli sebepler bulurlar: Dmitriy Lihaçov'a göre bu eğilim, bir çeşit “üst anlam” yakalama arzusunun (1979, s. 286); Yekaterina Borisovna Skorospelova'ya göre XX. yüzyıldaki klasik gerçekçi tipleştirme ilkesinin yerine evrenselleşmeyi ilke edinme isteğinin (2003, s. 59); Volf Şmid'e göre mitolojik düşünce yapısını tasvir etme emelinin (1998,s. 298); Mihail Golubkov'a göre ise modernist süslü üslup yöntemlerinin, özellikle de empresyonist ve ekspresyonist estetik ile ifade etme arzusunun bir sonucudur (2002, s. 230).

Edebiyat eleştirmenleri ve dil bilimciler (M. L. Gasparov, N. Ye. Yegninova, O. G. Yegorova, N. A. Kojevnikova, O.A. Korniyenko, L. A. Novikov, Ye. B. Skorospelova vd.) süslü nesrin temel sanatsal özelliklerine şu unsurları da eklemişlerdir: Dilsel kanunları reddetme ve yeni, zenginleştirilmiş bir edebiyat dili yaratma isteği; nesir ve nazım arasındaki sınırları kaldırma; montaj kompozisyonu; çağrışım yaratma ve sembolizm; nesrin ritmi, metin yapısının âhengini oluşturan biçemsel ve konusal yinelemeler; dilin tüm seviyelerinin "sözcüksel" (sözcük çokluğunun bağlamsal olarak geliştirilmesi), "sesbilimsel" (metin yapısında fonetik düzenlemeler); "sözdizimsel" (cümleleri karmaşıklaştırmak) araçlarını kullanarak okuyucuyu etkileme (Provotorova, 2011, s. 74).

Klasik olmayan anlatı türünün temelini yinelemeler oluşturur ve metne eşsizlik kazandırırlar (Lugovaya, 2016, s. 56). Ancak süslü nesrin özgünlüğü, sadece detayların basit yinelemelerden ibaret olması değil; mecazi söylemlere dayalı olmasıdır. Sovyet ve Rus dilbilimci L. A. Novikov'a göre "Süslü nesrin sözdiziminin ifade gücünün arttırllması, klasik olmayan özel bir anlatım tarzı olan empresyonist anlatım ile açıklanabilir" (1990, s. 156). Edebî metnin düzenlenmesinde en önemli rol, anlamsal ifade güçleri nedeniyle sözlü yinelemelere 
aittir. Yuriy Lotman, çeşitli tiplerdeki yinelemeleri "özel bir düşünce yoğunluğu vererek genel dil dokusunu oluşturan büyük karmaşıklığın anlamsal dokusu" olarak adlandırır (1970, s. 122). Yineleme, süsün dokusunu vurgulayan süslü nesirdeki metinleri ilişkilendirme aracıdır. Ritim ve kafiye kavramları ile ilişkilidir.

Süslü nesirde sıklıkla başvurulan yinelemelerin çeşitli türleri şunlardır:

* Aliterasyon (аллитерацция): Ritmik vurgulama ve ses sembolizmi işlevini yerine getiren aliterasyon yinelemesi. Ünsüz fonogram yinelemesi: "ştobı ogon', vzrıv, geyenna"

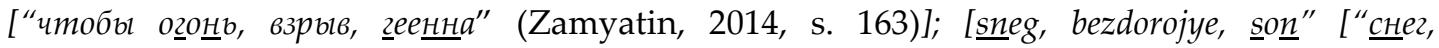
бездорожье, сом" (Fedin, 1974, s. 263)]; Na dne ovraga șumel çyorniy i pospeșny teper' klyuç"["Ha дне оврага циумел иерный и поспещиный теперь клюи" (Pilnyak, 2003, s. 299)]. Yevgeniy Zamyatin'in Biz eserinden alınan örnekte $-g$ - ve $-n$-sessizlerinin tekrarıla; Konstantin Fedin'in Kentler ve Yillar (Городa $u$ zoдbl) eserinden verilen örnekte -s-ve-n-ünsüzlerinin tekrarıyla; Boris Pilnyak'ın Tüm Yaşam (Целая жизнъ) eserinden alınan örnekte ise Rus dilindeki hışırtılı sessizlerden (шипящие согласные) olan -ş-ve -ç- sessizlerinin tekrarıyla söz konusu eserlerde bir ritim yakalandığı görülür.

* Asonans (асонанс): Süslü nesirde genellikle, nazımda aynı seslilerin tekrar edilmesi ile meydana gelen, vurguyu taşıyan aynı sesin tekrarı ile elde edilen ses oyunu olan asonansa başvurulur: "zolotaya igla oblaka, luç bagrovıy zakata" ["золотая игла, облака, ^уи

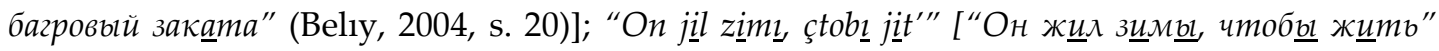
(Pilnyak, 2003, s. 302)]. Andrey Belıy'ın Petersburg eserinde aynı ünlü ses (-a- ünlüsü) vurgulu heceye rastlatılarak özel bir âhenk sağlanmıştır. Boris Pilnyak'ın Tüm Yaşam eserinden alınan örnekte ise - $i$-ve - - - ünlüleri tekrarlanarak aynı âhenk elde edilmiştir.

* $\quad$ Ön yineleme / anafor (анафора) (A....., A.....): Süslü nesirde birbirini izleyen cümlelerin başında aynı sözcügü ya da aynı sözcük öbeklerini kullanma sanatı olan ön yineleme söz sanatından bolca yararlanılır: Örneğin, “Utanıyorum, kardeşim, der Yegor gü̧̈lükle - Çok utanıyorum, seninle bu şekilde karşılaştığımız için. Kardeşim, beni öpmek hoşuna gitmeyecekse ӧрте!" [“<... Мне стьлно, брат, - говорит Егор трудно. - Мне очень стьыно, что так миь с тобою встретились. Брат, тебе неприятно меня цุеловать, не цุелуй!<...>" (Pilnyak, 2003, s. 59)].

* $\quad$ Art yineleme (эпифора) (.....A, .....A): Süslü nesirde ön yinelemenin yanı sıra birbirini takip eden cümlelerin sonunda aynı sözcügü ya da aynı sözcük öbeklerini kullanma sanatı olan art yinelemelerden de oldukça yararlanılır: "Etrafa bakın! Âdeta masal. Pelin otu kokuyor, çünkü bu bir masal..." ["<... Посмотрите кругом - сказка. Пахнет польюнью - потому что сказка <...>"(Pilnyak, 2003, s. 99)].

Süslü nesirde yinelemelerin haricinde ifade gücünü artırmak ve metne ritim ve âhenk vermek amacıyla en çok devriklemelerden, değişmecelerden ve sözdizimsel simetriden faydalanilır.

* Devrikleme (инверсия): Süslü nesirde, ritmi sağlamak için cümle içindeki sözcüklerin doğal düzeni kasıtlı olarak bozularak ve söz öbeklerinin yerleri değiştirilerek yapılan sözdizimsel yapılara ilişkin söz sanatıdır: "Adam, sonsuzluktaki karla kaplı yönünü kendi belirliyor: kayayı, yüksek ağact. Adam, karda vücudunu nehirde dümenin tekneyi burundan buruna götürd̈̈̆̈̈̈ gibi yönlendiriyor." ["<..> Человек сам намечает себе ориентиры в бескрайности снежной: скалу, высокое дерево, - человек ведёт своё тело по снегу так, как рулевой ведёт лодку по реке с мыса на миıс <...>" (Şalamov, 2016, s. 5)]. Hikâyede yazar "karla kaplı

SEFAD, 2020; (44): 85-102 
sonsuzluktaki" sözü yerine devrikleme yaparak "sonsuzluktaki karla kaplı" (в бескрайности снежной) ifadesini kullanir6.

* Sözdizimsel Simetri (синтаксическая симметрия): Sözdizimsel simetri ve ses yinelemeleri, nominatif dizinin destekleyici üyelerinin semantik birliğini pekiştirerek, nesir söyleminin nazım diliyle bütünleşmesine katkıda bulunan resimsel, görsel, süssel bir işlev

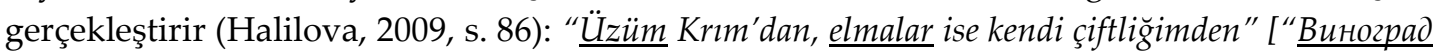
из Крымиа, яблоки из собственного имения" (Tinyanov, 1928, s. 7)]; "Sobalı yük vagonu karanlık. Sobal yük vagonu sessiz." ["В теплушке миак. B теплушке безмолвие" (Pilnyak, 2003, s. 153)]; "Yine kulisler ve yine aktrisler" ["Onsmb ㅆㅅucbl u onsmb aкmpucbl" (Tinyanov, 1928, s. 11)];

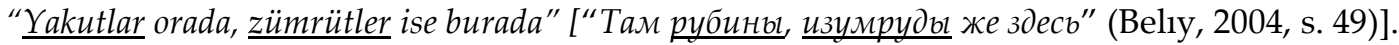

Süslü nesrin genel eğilimi, konuşma konusunu görsel bir imge ile sunma arzusu, hem maddi hem manevi olana yayılarak tasvir edilenin somutlaştırılması şeklindedir. Değişmece, soyut olana somutluk vermek ve somut olanın maddiliğini daha da vurgulamak için kullanılır (Kojevnikova, 1976, s. 60).

Süslü nesrin özgünlüğü, sadece değişmecelerin temelinde ortaya çıkan detayların yinelemelerinden ibaret değildir. Süslü nesirde değişmeceler arasında en çok kullanılanlar semboller, deyim aktarmaları (eğretileme, istiare, metafor) ve ad aktarmalarıdır (mecazı mürsel, düzdeğişmece, metonimi). Söz konusu dilbilimsel paradigmanın diğer ögeleri benzetme, karşılaştırma ve metamorfozdur [başkalaşım (метаморфоза)] (Brevnova, 2002, s. 71).

Süslü nesrin birçok yönteminin açıklamasını yinelemelerle, paralellikle (параллелизм) dolu ve ritmik olarak düzenlenmiş bir sözdizimine sahip olan dinî metinlerin taklitlerinde aramak gerekir. Edebî metne büyülü, telkin (hipnoz) edici bir olgu olarak bakma, süslü nesir yazarlarının gerçeği sinestetik (eşduyumlu) olarak (kokuyu çiçek gibi, sesi çiçek gibi, sesi koku gibi) algılamalarına ve metinlerde bu şekilde aktarmalarına yol açmaktadır (Zimina \& Rus-Bryuşinina, 2015, s. 11). Bu anlamda, çağdaş Rus süslü nesri, sadece gözler tarafından okunmak için değil aynı zamanda yüksek sesle okunmak için inşâ edilmiştir. İşte o zaman, okuyucuda dilin tüm seviyelerinin (sözcüksel, sesbilimsel, sözdizimsel) semantik bir genellemesine dayanan görsel ve işitsel duyguların birleşimi ortaya çıkar. Böylece yazar tarafından okuyucuda oluşması istenen sinestetik algı etkisi gerçekleşir (Brevnova, 2002, s. 85).

\section{SONUÇ}

Türk ve Rus edebiyatındaki süslü nesir, taşıdıkları özellikleri ve tarihsel süreçleri bakımından karşılaştırıldığında şu sonuçlara ulaşılmıştır:

Türk ve Rus edebiyatlarında süslü nesrin ilk örnekleri genellikle dinî içerikli eserlerde görülür. Örneğin, Türk edebiyatında süslü nesre ilk kez Sinan Paşa'nın Tazarru'nâme adlı eserinde rastlanmaktadır. Tazarru'nâme, dinî-tasavvufî içerikli bir eserdir. Rus edebiyatında da süslü nesrin ilk örnekleri XV. yüzyılda Stefan Permskiy'nin Yaşamı ve Sergiy Radonejskiy'nin Yaşamı eserlerinde görülür. Söz konusu eserler azizlerin yaşam öykülerini ele almaktadir.

${ }_{6}^{6}$ Varlam Şalamov'un Kolıma Öyküleri'nden Kar Boyunca öyküsünün süslü nesir bağlamında daha ayrıntılı analizi için bkz.: Tetik, K. (2019). Şiirsel düzyazı ve Varlam Tihonoviç Şalamov'un "Kolıma Hikâyeleri"nden "Kar Boyunca" hikâyesi örneğinde şiirsel düzyazının üslup özellikleri. E. İnanır, O. Köse ve Y. Ulutürk (Ed.), Siyasi, sosyal ve kültürel yönleriyle Türkiye ve Rusya içinde (C. 1, s. 227-239). Ankara: Berikan Yay. 
Türk ve Rus edebiyatında süslü nesir, nazmın nesre oranla daha fazla ön planda olduğu dönemlerde görülür. Türk edebiyatında süslü nesir, Divan Edebiyatı döneminde; yine aynı şekilde Rus edebiyatında süslü nesir, nazmın ön planda olduğu Rus şiirinin parlak dönemi olan Gümüş Çă̆ döneminde ortaya çıkmıştır.

Türk edebiyatındaki süslü nesirde, birbiriyle uyumlu, âhenkli ve simetrik yapıların baştan sona yer aldığı, bu yapıları oluşturan en önemli unsurun da seci olduğu tespit edilmiştir. Ayrıca bu nesirde âhengin; sözcük tekrarları, aliterasyonlar, asonanslar, redif, cinas gibi sese dayalı sanatlarla benzetme, tasvir, mecaz gibi anlam sanatlarının bolca kullanılarak sağlandığı görülmüştür. Bu özelliklerin Rus edebiyatındaki süslü nesir örneklerinde de yer aldığı tespit edilmiş olup edebiyatta estetik kaygının, hangi dilde ve kültürde olursa olsun benzer tavır sergilediği kanısına varılmıştır.

Her iki edebiyatta da nesir türünün doğuşunda şiirsel ifadenin daha kalıcı ve etkileyici etkisinin bulunduğu görülmüştür. Bunun yanı sıra süslü nesirde, her iki edebiyat sanatçlarının da öncelikli tavrının sanatsal kaygı olduğu; hünerlerini sergilemek amacıyla zaman zaman sözü anlamın önüne geçecek kadar ağırlaştırarak külfetli bir nesir üslubu yarattıkları benzer bir yön olarak gözlemlenmiştir.

Her iki edebiyatta süslü nesrin ortaya çıkış tarihleri incelendiğinde Türk edebiyatında XV. yüzyıl ortaları olarak görülmüştür. Fakat, "süslü nesir" tarzı XV-XVIII. yüzyıllar arasındaki klasik edebiyat nesirlerinde ortaya çıkmış olmasına rağmen XIX. yüzyıl Tanzimat Edebiyatında (her ne kadar dilde sadeliği savunsalar da) Namık Kemal'in bir kısım romanlarında romantik bakış açısına dayalı sanatlı söyleyişe rastlamak mümkündür. Ayrıca XIX. yüzyıl sonları XX. yüzyıl başlarına rastlayan Servet-i Fünun Dönemi nesrinde de Halit Ziya Uşaklıgil, Cenap Şahabettin, Süleyman Naif, Abdülhak Şinasi Hisar başta olmak üzere söz konusu yazarların, "sanat sanat içindir" anlayışı ve estetik kaygıyla Arapça, Farsça ve hatta Fransızca sözcüklerle yüklü, bol tamlamall, sanatlı, süslü bir üslup geliştirdikleri; Parnasyenlerin de etkisiyle o güne kadar hiç kullanılmamış olan benzetmeli, mecazlı yeni kavramlar, yeni söz kalıpları ve yeni hayal unsurları ile eserlerinde âhenk yaratma çabası içine girdikleri görülür. Neticede XX. yüzyıldan itibaren Türk edebiyatında dilde sadeleşme akımlarının etkisiyle sanatlı anlatımdan uzaklaşılmaya başlanmıştır.

Rus edebiyatında da aynı şekilde süslü nesrin kökleri Eski Rus Edebiyatı (XI-XVII. yüzyıllar) olarak adlandırılan döneme, XV. yüzyıla rastlar. Ancak başlangıç tarihi olarak 1920'li yıllar kabul edilir. Süslü nesir türünde en fazla eser 1920'li yıllarda verilmiştir. En parlak dönemini 20'li yıllarda yaşayan süslü nesir, XX. yüzyılın ikinci yarısında da görülür, hatta XI. yüzyılda Çağdaş Rus Edebiyatı döneminde de (örneğin, Viktor Pelevin'in Omon Ra (1992), " $P$ " Kuşağı (Generation " $\Pi$ ", 1999) eserlerinde) varlığını sürdürür. Ancak bu varoluş, etkisini kaybederek, başkalaşarak edebiyatta kendisini gösterir.

\section{SUMMARY}

Ornate prose is one of the main prose types of classical Turkish literature (plain, medium and ornate). The fascinating power of poetry, the leading literary genre of the Divan Literature Period in Turkish literature, also influenced prose. Therefore, the words of Arabic and Persian origin are commonly found in the period of classical Turkish literature, and the concern of making art develops in prose as well as in poetry. The result is ornate prose with a harmonious and rhythmic tone, in which flashy metaphors in poetry, various literary arts and flowery rhymes abound.

SEFAD, 2020; (44): 85-102 
In this study, the emergence of the ornate prose in Turkish and Russian literature, its developmental stages, stylistic features, common features and differences have been clarified from general to specific comparatively.

When the ornate prose in Turkish and Russian literature is compared in terms of its characteristics and historical processes, the following conclusions have been reached:

The first examples of ornate prose in Turkish and Russian literatures are generally seen in works of religious content. For example, the ornate prose in Turkish literature is found for the first time in Sinan Pasha's Tazarru'nâme, which is a religious-mystical work. In Russian literature, the first examples of ornate prose are seen in the works of Life of Saint Stephen, Bishop of Perm and Life of Saint Sergius of Radonezh in the 15th century, which deal with the life stories of saints.

In the ornate prose in Turkish literature, it has been determined that the harmonious and symmetrical structures are located entirely, and that the most important element forming these structures is rhyme. Besides, it has been observed in this prose that harmony is ensured by abundantly using; a) sound-based arts, such as word repetitions, alliterations, assonances, radif (repetition of common words) and pun, b) semantic arts, such as analogy, depiction and metaphor, c) repetition-based arts, such as pre-iteration and post-iteration. These features have been determined to be included in ornate prose examples in Russian literature as well, and it is concluded that aesthetic anxiety in literature shows a similar attitude regardless of language and culture.

In both literatures, it has been seen that poetic expression has a more permanent and impressive influence on the emergence of prose. In addition, in ornate prose, it has been observed as a similar aspect that the primary attitude of both literary artists is artistic concern, and that in order to showcase their skills, they sometimes create a burdensome prose style by making the word heavier than the meaning.

When the emergence dates of ornate prose in both literatures are examined, it is seen in Turkish literature as the mid-15th century. Sinan Pasha was the leading representative of the ornate prose in the 15th century. Tazarru'nâme, his most important work, was the first major work of the Turkish artistic prose. Apart from Sinan Pasha, artists such as Âşık Çelebi, Sâlim, Safâŷ̂, and writers of journal (münşeât), including some official and private correspondence, used ornate prose style. Fuzûlî's Şikâyetnâme, Nergisî's Hamse and Veysî's Münşeât and Dürretü't Tâc can be shown as the most extreme examples of this prose. Although the ornate prose appeared in classical literary prose between the 15th and 18th centuries, it is possible to come across artistic discourse based on a romantic perspective in some of the novels of Namik Kemal in 19th century Tanzimat (Reform) Literature period (although it advocates simplicity in the language). In addition, it is seen in the prose of Servet-i Fünun (The New Literature Movement), which dates from the end of the 19th century to the beginning of the 20th century, that authors, especially Halit Ziya Uşaklıgil, Cenap Şahabettin, Süleyman Naif and Abdülhak Şinasi Hisar, developed an artistic ornate style full of Arabic, Persian and even French words and phrases with the understanding of "art is for art" and aesthetic anxiety and attempted to create harmony in their works in a novel way with simile, metaphorical new concepts, new phrases and new imagination elements with the influence of the Parnassians. As a result, from the 20th century onwards, 
artistic expression has started to be avoided due to the simplification currents in the language in Turkish literature.

Similarly, in Russian literature, the roots of the ornate prose dates back to the period called the Old Russian Literature (11-17th centuries), the 15th century. However, the emergence of the ornate prose is generally associated with the Silver Age. The boundaries between prose and poetry were removed from the Silver Age onwards, the strong poetry period, following the Golden Age, the strong prose period. With the combination of verse and prose, ornate prose emerges. Many poets who want to try themselves in prose in the early 1920s create an extraordinary style without rejecting their past experiences. The fact that poetry penetrated into prose is a harmonious and original event that conforms to the conditions of the afore-mentioned literary period and results in the emergence of ornate prose, a non-classical narrative type in prose. Most works of ornate prose were created in the 1920s. The founder of the ornate prose is the symbolist poet and writer Andrey Bely. The Symphonies [(Dramatic Symphony, 1902); Northern Symphony (1904]; Return (1905), Goblet of Blizzards (1908), Petersburg (1913) and Kotik Letaev (1917) of Andrey Bely are among the first examples of the ornate prose in the 20th century. Similar to Andrey Bely, Aleksei Remizov is considered one of the founders of the ornate prose with his work, The Reserved Word to the Russian People (1918). Ornate prose is seen intensely in the first half of the 1920s. Ornate prose, seen in the works of writers, such as Boris Pilnyak (The Naked Year, 1922), Yevgeny Zamyatin (We 1924), Alexander Serafimovich (The Iron Flood, 1924), are also seen in the second half of the 20s in the works of writers, such as Mikhail Bulgakov (The White Guard, 1925), Maxim Gorky (The Artamonov Business, 1925), Konstantin Fedin (Cities and Years, 1927), Osip Mandelstam (The Egyptian Stamp, 1928), Yury Tynyanov (Death of the Vazir-Mukhtar, 1928). Ornate prose maintains its influence in the 30s, e.g. Vladimir Nabokov (Despair, 1934) and Boris Poplavsky (Home from Heaven, 1936-1938). This literary tendency takes place in Russian literature in the second half of the 20th century as well. For instance, Varlam Shalamov's Kolyma Stories (1966-1967) and Boris Pilnyak's A Whole Life (1988) are indications that the traditions of ornate prose remained important in the second half of the 20th century. The ornate prose, which experienced its brightest period in the 20s, is also seen in the second half of the 20th century and continues to exist even in the 21st century, in the period of contemporary Russian literature (for instance, in the works of Viktor Pelevin's Omon $\mathrm{Ra}$ (1992), Generation $P$ (Generation " $\Pi ", 1999))$. However, this existence manifests itself in literature by losing its influence and transforming itself.

SEFAD, 2020; (44): 85-102 
Makale Bilgileri

Etik Kurul Karart:

Katılımcı Rızası:

Mali Destek:

Çıkar Çatışması:

Telif Hakları:

Article Information

Ethics Committee Approval:

Informed Consent:

Financial Support:

Conflict of Interest:

Copyrights:
Etik Kurul Kararından muaftır.

Katılımci yoktur

Çalışma için herhangi bir kurum ve projeden mali destek alınmamıştır.

Çalışmada kişiler ve kurumlar arası çıkar çatışması bulunmamaktadır.

Telif hakkına sebep olacak bir materyal kullanılmamıştır.

Exempt from the Ethics Committee Decision.

No participant

No financial support from any institution or project.

No conflict of interest.

No material subject to copyright is included. 


\section{KAYNAKÇA}

Ahmedov, S. H. \& Alihanova, İ. Ya. (2013). Ponyatiye ornamentalizma v literaturovedenii i proza Ahmedhana Abu-Bakara. Vestnik instituta yazlka, literature $i$ iskusstva imeni G. Tsadası, 3, 93-98. Erişim adresi: https://elibrary.ru/download/elibrary_20499120_51941354.pdf

Bahtin, M. M. (1975). Voprosı literature i estetiki. Moskva: Hudojestvennaya literatura.

Banarlı, N. S. (1998). Resimli Türk edebiyatı tarihi I. İstanbul: MEB Yay.

Belaya, G. A. (1978). Rojdeniye novih stilevıh form kak protsess preodoleniya "neytralnogo" stilya. N. K. Gey (Ed.), Teoriya literaturnih stiley. Mnogoobraziye stiley sovetskoy literature: Voprosı tipologii. içinde (s. 460-485). Moskva: Nauka.

Belaya, G. A. (1978). Stili vremya ("avtoritetnystil" i ego problemetika). N. K. Gey (Ed.), Teoriya literaturnı stiley. Mnogoobraziye stiley sovetskoy literature: Voprosı tipologii. içinde (s. 231-256). Moskva: Nauka.

Beliy, A. (2004). Peterburg (2.bs.). Sankt-Peterburg: Nauka.

Brevnova, S. V. (2002). Sistemno-funksionalnoye opisaniye ornamentalnoy prozı hudojestvennogo teksta (na materiale proizvedeniy Ye. Zamyatina i B. Pilnyaka). (Yayımlanmamış yüksek lisans tezi). Kuban Devlet Üniversitesi, Krasnodar.

Çaldak, S. (2006). Eski Türk edebiyatında nesir (düz yazı). Bilimin ve aklın aydınlığında eğitim, 7(77-78), 74-90. Erişim adresi: http://turkoloji.cu.edu.tr/ESKI\%20TURK\%20\%20EDEBIYATI/suleyman_caldak_eski_tu rk_edebiyatinda_nesir.pdf.

Dragomiretskaya, N. (1965). Teoriya literaturı. osnovnıye problemı v istoriçeskom osveşçenii. Stil'. Proizvedeniye. Moskva: Literaturnoye razvitiye.

Fedin, K. (1974). Goroda i godl. Brat'ya. Moskva: Hudojestvennaya literatura.

Golubkov, M. M. (2002). Russkaya literatura xx veka: Posle raskola. Moskva: Aspekt.

Golubkov, M. M. (2016). İstoriya russkoy literaturnoy kritiki xx veka. Moskva: Yurayt.

Gülsevin, G., Turan, F., Kartallığlu, Y., Develi, H. \& Duman, M. (2012). XVI-XIX. yüzyıllar Türk dili. Eskişehir: Anadolu Üniversitesi Yay.

Halilova, D. M. (2009). Ritmiçeskaya organizatsiya nominativnıh ryadov v russkoy ornamental'noy proze. Vestnik tsentra mejdunarodnogo obrazovaniya Moskovskogo gosudarstvennogo universiteta, 4, 83-86. Erişim adresi: https://elibrary.ru/download/elibrary_13019952_95471932.pdf

İvanov, V. V., Paperniy, Z. S. \& Parnis, A. Ye. (2000). Mir Velimira Hlebnikova. Stat'i. İssledovaniya (1911-1998). Moskva: Yazıki russkoy kul'turı.

İz, F. (1996). Eski Türk edebiyatında nesir. Ankara: Akçağ Yay.

Kojevnikova, N. A. (1976). İz nablyudeniy nad neklassiçeskoy ("ornamental'noy”) prozoy. İzvestiya, 35(1), 55-66. Erişim adresi: https://www.twirpx.com/file/2182439/.

Kvyatkovskiy, A. P. (2013). Poetiçeskiy slovar'. Moskva: İzdatel'skiy tsentr Rossiyskogo gosudarstvennogo gumanitarnogo universiteta.

Lihaçov, D. S. (1979). Poetika dreonerusskoy literaturı. Moskva: Nauka.

Lotman, Yu. M. (1970). Struktura hudojestvennogo teksta. Moskva: İskusstvo.

SEFAD, 2020; (44): 85-102 
Lugovaya, N. V. (2016). Figurı pribavleniya kak smısloobrazuyuşçeye i ritmoobrazuşçeye sredstvo ornamental'noy prozı B. Poplavskogo (na primere romana “Domoy s nebes). Trudı Rostovskogo gosudarstvennogo universiteta putey soobş̧̧eniya, 1, 56-60. Erişim adresi: https://elibrary.ru/download/elibrary_27386521_91897256.pdf .

Mengi, M. (2007). Eski Türk edebiyatında nesir: Gelişimi ve kaynakçası. Türkiye Araştırmaları Literatür Dergisi, 5(10), 43-76. Erişim adresi: https://www.academia.edu/5697549/Eski_T\%C3\%BCrk_Edebiyat\%C4\%B1nda_Nesir_G eli\%C5\%9Fimi_ve_Kaynak\%C3\%A7as\%C4\%B1_The_Prose_in_Old_Turkish_Literature _Its_Development_and_Bibliography_M\%C4\%B0NE_MENG\%C4\%B0.

Novikov, L. A. (1990). Stilistika ornamental'noy prozı Andreya Belogo. Moskva: Nauka.

Pilnyak, B. (2003). Sobraniye soçineniy v 6 tomah (C. 1): Golıy god: Roman; povesti; rasskazı. Moskva: TERRA.

Puşkin, A. (1937). Yevgeniy Onegin. Parij: Étoile.

Skorospelova, Y. B. (2003). Russkaya proza xx veka: Ot A. Belogo ("Peterburg") do B. Pasternaka ("Doktor Jivago"). Moskva: TEIS.

Şalamov, V. (2016). Kolımskiye rasskazı. Sankt-Peterburg: Azbuka.

Schmid, W. (1998). Proza kak poeziya: Puşkin. Dostoyevski. Çehov. Avangard. Sankt-Peterburg: INAPRESS.

Şulova, Y. A. (2016). Traditsii ornamental'noy prozı A. Belogo v romane V. İ. Guseva "Ognenniy veter yuga." L. F. Alekseyeva (Haz.), II Mejdunarodnaya nauçnaya konferentsiya "Slovesnoye iskusstvo Serebryanogo veka i russkogo zarubejya v kontekste epohi ("Smirnovskiye çteniya")". Sbornik statey içinde (s. 268-272). Moskova: Moskova Devlet Üniversitesi Yay.

Tetik, K. (2019). Şiirsel düzyazı ve Varlam Tihonoviç Şalamov'un "Kolıma Hikâyeleri"nden "Kar Boyunca" hikâyesi örneğinde şiirsel düzyazının üslup özellikleri. E. İnanır, O. Köse ve Y. Ulutürk (Ed.), Siyasi, sosyal ve kültürel yönleriyle Türkiye ve Rusya içinde (C. 1, s. 227-239). Ankara: Berikan Yay.

Tetik, K. (2020). Bir skaz örneği: İsaak Babel'inTuz adlı öyküsü. O. Köse (Ed.), Siyasi, sosyal ve kültürel yönleriyle Türkiye ve Rusya içinde (C. 4, s. 205-219). Ankara: Berikan Yay.

Tinyanov, Yu. (1928). Smert Vizir-Muhtara. "Public Domain".

Tomaşevskiy, B. V. (1959). Stih i yazık. Moskva: Hudojestvennaya literatura.

Tulum, M. (Haz.). (2001). Tazarru'nâme. Ankara: MEB Yay.

Uşakov, D. N. (2012). Tolkovıy Slovar' russkogo yazıka. Moskva: Al'ta Print.

Zamyatin, Ye. (2014). Mi. Sankt-Peterburg: Azbuka-klassika.

Zimina, N. \& Rus-Bryuşinina, İ. V. (2015). Hudojestvenniy kontsept kak yedinitsa individual'nogo soznaniya $\mathrm{i}$ ornamental'no stidiostilya (na primere tvorçestva $\mathrm{V}$. Pelevina). Nauçnıye trudı KUBGTU, 5, 9-16. Erişim adresi: https://elibrary.ru/download/elibrary_23498452_46704995.pdf. 